\title{
Law Enforcement In The Judge's Verdict Against Narcotics Abuse For Yourself
}

\section{Puji Andrayani*) and Rakhmat Bowo Suharto**)}

*) Student of Masters (S2) of Law Faculty of Law Unissula and Prosecutors at the Semarang City Attorney, email: puji_andrayani@yahoo.com

${ }^{* *}$ Faculty of Law, Universitas Islam Sultan Agung (UNISSULA) Semarang

\begin{abstract}
The crime of narcotics abuse is an extraordinary crime, because the impact is very detrimental not only to the user but also the community, so that every crime must be punished, and the law in this case Act No. 35 of 2009 must be upheld. This study aims to identify and describe law enforcement in the judge's decision on the crime of narcotics abusers for oneself from a justice perspective. This study uses a normative juridical approach to analysis descriptive. The data used is secondary data obtained through library research, which is then analyzed qualitatively. The results of this study are that law enforcement in the judge's decision on the crime of narcotics abusers for themselves in the perspective of justice is based on the judge's consideration in determining the severity or lightness of the punishment imposed on the defendant according to the principle of balance between guilt and illegal acts. Narcotics abusers themselves must be viewed as victims, so they must be rehabilitated. Supreme Court Circular No. 4/2010 is used as a reference for judges to determine whether a person is an individual abuser or not. Narcotics abusers themselves must be viewed as victims, so they must be rehabilitated. Supreme Court Circular No. 4/2010 is used as a reference for judges to determine whether a person is an individual abuser or not. Narcotics abusers themselves must be viewed as victims, so they must be rehabilitated. Supreme Court Circular No. 4/2010 is used as a reference for judges to determine whether a person is an individual abuser or not.

Keywords: Justice, Narcotics, Law Enforcement, Judge's Verdict
\end{abstract}

\section{Introduction}

In the current era of globalization, which is marked by the development of science and technology, it provides benefits for humans not only in terms of communication but also makes it easier for humans to carry out work, even their daily activities. However, the development of science and technology also has a negative impact if it is misused, such as to commit crimes.

This proves that there is an adage which states that the poorer a nation is, the higher the level of conventional crimes, such as theft, robbery, fraud, murder, and so on. ${ }^{1}$ not quite true. The negative impact of the development of technological science has made the types of crimes or criminal acts increasingly diverse with increasingly sophisticated modus operandi, for example corruption, money laundering, narcotics crime, cyber crime, and so on. These crimes are included in extraordinary crimes (extra ordinary crimes) or crimes that do not have human rights and violate human rights.

A criminal act is an act which is prohibited by law and punishable by punishment, in which the definition of an act here is not only active (doing

1Edi Setiadi and Kristian, 2017, Sistem Peradilan Pidana Terpadu dan Sistem Pe-negakan Hukum Di Indonesia, First Edition Kencana Prenada Media, Jakarta, p. 1. 
something that is actually prohibited by law), but also an act that is passive (not doing something that is illegal). truth required by law). ${ }^{2}$

As mentioned, one of the crimes included in extraordinary crimes is the crime of narcotics abuse. Basically, narcotics are useful especially for research or for treatment, however, currently there are not a few people who use narcotics deviating from the established regulations, not to mention the circulation of narcotics in the community which has caused many victims.

The crime of narcotics abuse seems to never stop, even though the Indonesian government has called for eradication and prevention, these efforts have not been successful. The problem of narcotics and illegal drug abuse is a complex problem, so it requires comprehensive prevention efforts involving multidisciplinary, multisectoral, and active community participation. ${ }^{3}$ The existence of a criminal act of narcotics abuse, then there are legal rules that have been violated, in this case is Act No. 35 of 2009 concerning Narcotics. According to E. Utrecht, law is a set of rules (orders and prohibitions) that take care of the order of a society and therefore must be obeyed by that society. ${ }^{4}$

In general, the community recognizes law as a rule, norm, guideline, behavior, or statutory regulation which, if violated, will be subject to sanctions. This understanding is very easy for people to understand, because for people who are wrong or violating the rules, they must be punished. ${ }^{5}$

The law cannot be upheld by itself, meaning that the law (legal substance) is unable to realize the promises and wills contained in the law (regulations) on its own. These promises and wishes, for example, are to give someone the right, give protection to someone, impose punishment on someone who meets certain conditions, and so on. ${ }^{6}$

In this case, the law which has been violated must be enforced. Through this law enforcement, law becomes a reality. Law enforcement is the pillar (main pillar) that strengthens the fundamentals that support the welfare of society, in various aspects of life. ${ }^{7}$

Soerjono Soekanto argues that conceptually, the essence and meaning of law enforcement lies in the activity of harmonizing the relationship of values that are

\footnotetext{
2Teguh Prasetyo, 2010, Hukum Pidana, Rajawali Press, Jakarta, p. 48.

${ }^{3}$ Arif Hidayat dan Sri Endah Wahyuningsih, Juni 2018, Role of Prosecutor General Pro-secution of Actors in The Implementation of Abuse of Narcotics Crime (Case Study in Magelang District Attorney), Jurnal Daulat Hukum, Vol. 1 No. 2, Faculty of Law, Sultan Agung Islamic University, Semarang, p. 446.

4Juhaya S. Praja, 2011, Teori Hukum dan Aplikasinya, Cetakan Kesatu, Pustaka Setia, Bandung, p. 169.

5Jawade Hafidz Arsyad dan Dian Karisma, 2018, Sentralisasi Birokrasi Pengadaan Barang \& Jasa Pemerintah, First Edition Sinar Grafika, Jakarta, p. 63.

6Viswandro, Maria Matilda dan Bayu Saputra, 2015, Mengenal Profesi Penegak Hukum, Buku Rujukan Berkarier Di Bidang Hukum, Hakim-Jaksa-Polisi-Advokat, First Edition Pustaka Yustisia, Yogyakarta, p. 3.

${ }^{7}$ Siti Malikhatun Badriyah, 2010, Penemuan Hukum Dalam Konteks Pencarian Keadilan, First Edition Badan Penerbit Universitas Diponegoro, Semarang, p. 38.
} 
outlined in solid principles and embodying actions and attitudes as a series of final stage value descriptions, to create, and maintain peace in social life. ${ }^{8}$

In law enforcement, involving law enforcers as the executor, including judges through fair decisions. Judges are a part of law enforcement which is a sub system in the criminal justice system. Judges have a very noble duty in determining the fate / color of the law in the eyes of the public when viewed from their duties and authority as the party to decide the case. Judges are the center of attention of the community, because every decision will be judged by the community whether the decision is fair or unfair. ${ }^{9}$

The increasing number of narcotics abuse from year to year is inseparable from the lightness of the verdict handed down by the judge, the judge in making a decision should pay attention to 3 (three) important elements, namely justice, legal certainty and benefit. ${ }^{10}$

So far, the abuse of narcotics for oneself has received light criminal sanctions or if it is not given sanctions in the form of rehabilitation, so many people underestimate and even repeat the action. The criminal sanctions imposed by judges on perpetrators of criminal acts of narcotics abuse for themselves have not been able to provide a deterrent effect on the perpetrators, and have not been maximized as an effort to tackle and eradicate narcotics crime.

\section{Research Methods}

The type of research used in writing this legal journal is normative juridical. Normative juridical research is research that is focused on examining the application of the rules or norms in positive law, ${ }^{11}$ which in this case relates to law enforcement in the judge's decision on the criminal offense of narcotics abusers for themselves from the perspective of justice. This research is a descriptive analysis, because the researcher wishes to describe or explain the subject and object of the research, which then analyzes and finally draws conclusions from the results of the study. ${ }^{12}$ The data used in this research is secondary data. Secondary data is data obtained from library materials through library research, and this data is also obtained from agencies / institutions related to the purpose of this research. ${ }^{13}$ According to the data that has been obtained during conducting research by reading library books, then analyzed. The analysis used in this research is qualitative data analysis.

\footnotetext{
8Soerjono Soekanto, 2016, Faktor-faktor yang Mempengaruhi Penegakan Hukum, First Edition, 14 Printed, Raja Grafindo Persada, Jakarta, p. 5.

${ }^{9}$ Erna Dewi, Juli 2010, Peranan Hakim Dalam Penegakan Hukum Pidana Indonesia, Pranata Hukum, Vol. 5 No. 2, Faculty of Law, University of Lampung, Lampung, p. 95.

10 Dahlan, 2017, Problematika Keadilan Dalam Penerapan Pidana Terhadap Penyalah-guna Narkotika, First Edition Deepublish, Yogyakarta, p. 119.

11Jhonny Ibrahim, 2011, Teori dan Metodologi Penelitian Hukum Normatif, Bayumedia, Malang, p. 295.

12Mukti Fajar ND and Yulianto Achmad, 2010, Dualisme Penelitian Hukum Normatif dan Empiris, Pustaka Pelajar, Yogyakarta, p. 183.

${ }^{13}$ Soeratno dan Lincolin Arsyad, 2003, Metodologi Penelitian Untuk Ekonomi Dan Bisnis, UPP AMP YKPN, Yogyakarta, p. 173.
} 


\section{Results and Discussion}

Act No. 35 of 2009 as a rule of law regulates the legal use of narcotics, that is, it is used in the field of medicine or research, and may not be used for interests outside those regulated in law. Traditionally and modern, narcotics are widely used for medical purposes. ${ }^{14}$

As stated by Edi Setiadi and Rena Yulia, one of the functions of law is to protect human interests. The law has a purpose. The law has a goal to be achieved. The main purpose of law is to create an orderly society to create order and balance. By achieving order in society, it is hoped that human interests will be protected. In achieving this goal, the law has the duty to divide rights and obligations between individuals in society, share authority and regulate ways to solve legal problems and maintain legal certainty. ${ }^{15}$

Narcotics are drugs or substances that can be used in the field of medicine or health care and scientific development, however, on the other hand, narcotics can create dependence and are very detrimental to the user if used without strict and thorough supervision. The misuse of narcotics will have a bad impact on the user and the surrounding environment, the misuse of narcotics has a very large and wide impact, so that narcotics abuse is a very dangerous crime, so that law enforcement efforts are needed against the Narcotics Law. The misuse of narcotics, in fact, is a criminal act, so that the perpetrator should carry out a legal process like law enforcement in other criminal cases. ${ }^{16}$

Law enforcement, including criminal law enforcement, is a series of processes of applying abstract legal values, ideas and ideals into legal objectives. Legal objectives or legal ideals contain legal morals such as legal justice and truth. ${ }^{17}$

Criminal law enforcement can be conceptualized in a simple way as a (criminal) law enforcement apparatus working process in examining a person suspected of committing a crime to ascertain whether that person is legally guilty. The examination is a gradual process: starting from investigation / investigation, prosecution, to determination of punishment. This is what is known as the criminal justice process. ${ }^{18}$

In the criminal justice system, judges have a very important role in law enforcement, especially in relation to the imposition of criminal sentences against perpetrators of criminal acts, and decisions must always be based on justice based on law. As explained in Act No. 48 of 2009 concerning Judicial Power, all judicial decisions in addition to containing the reasons and basis for the decision, also

\footnotetext{
14 Yasonna H. Laoly, 2019, Jerat Mematikan, Perspektif Kesejahteraan Ekonomi Dalam Penyalahgunaan Narkotika, First Edition Pustaka Alvabet, Ciputat Tangerang, p. 25.

${ }^{15}$ Edi Setiadi dan Rena Yulia, 2010, Hukum Pidana Ekonomi, First Edition Edisi Pertama, Graha Ilmu, Yogyakarta, p. 7.

${ }^{16}$ Aulia Fadhli, 2018, NAPZA, Ancaman, Bahaya, Regulasi dan Solusi Penang-gulangannya, First Edition Gava Media, Yogyakarta, p. 11

${ }^{17}$ Maroni, 2016, Penegakan Hukum Pidana yang Humanistik Untuk Mewujudkan Keadilan Spiritual, dalam Sulaiman (Ed.), Pemikiran Hukum Spiritual Pluralistik, Sisi Lain Hukum yang Terlupakan, Second Edition, Thafa Media, Yogyakarta, p. 313.

18Theodorus Yosep Parera, 2016, Advokat dan Penegakan Hukum, First Edition Genta Press, Yogyakarta, p. 19.
} 
contain certain articles in the relevant laws and regulations or a written source of law which is used as a basis for judging. Apart from that, it was also stated that judges were obliged to explore, follow and understand the legal values and sense of justice that live in society.

One of the basic considerations of the judge in determining the severity or lightness of the sentence imposed on the defendant is always based on the principle of balance between wrongdoing and illegal acts. The judge's decision must state the reasons that the sentence imposed is in accordance with the nature of the act, the circumstances covering the act, the defendant's personal condition. ${ }^{19}$

In the event that a judge renders a verdict on a criminal offender who abuses narcotics for himself, it has broad consequences, both directly related to the perpetrator of the criminal act, as well as with the community at large. This is especially true if the verdict passed is considered to be inaccurate or because of disparities in the imposition of crimes between one criminal and another, even though the articles violated are the same. If the difference in the judge's verdict is very confusing, it will cause a strong reaction from the perpetrators of the crime and from the community.

Judges need very thorough consideration in determining and imposing criminal sanctions for perpetrators of criminal acts of narcotics misuse for themselves, because narcotics abusers themselves are considered victims, so that in imposing criminal offenses against narcotics, they must consider the circumstances. contained in the defendant, his curriculum vitae and the defendant's social and economic conditions can serve as a guide for a judge to pass a sentence.

The judges' considerations in making a verdict can be in the form of: First, juridical considerations, namely the indictment of the public prosecutor, witness testimony, testimony of the defendant, evidence, and articles in Act No. 35 of 2009. Second, considerations non-juridical, namely the result of the defendant's actions, the defendant's self-condition, and burdensome and mitigating things. ${ }^{20}$

Act No. 35 of 2009 regulates criminal penalties for narcotics offenders. In Article 111 of Act No. 35 of 2009 it regulates the control of narcotics group I in the form of plants, and in Article 112 of Act No. 35 of 2009 regulates the control of narcotics in the form of non-plants. Especially for the perpetrators of narcotics abuse for themselves, it is regulated in Article 127 paragraph (1), paragraph (2) and paragraph (3) of Act No. 35 Of 2009.21

In preparing the indictment, the public prosecutor often uses Article 111 and Article 112 of Act No. 35 Of 2009 to charge the perpetrator of a crime of narcotics abuse with the evidence found at the time of arrest that it is estimated that it is sufficient to be used for a day. By using Article 111 and Article 112 of the Act No. 35 Of 2009 against narcotics abusers, will result in narcotics abusers being sentenced to a minimum of 4 (four) years in prison, plus a fine which, if not paid, will be replaced by imprisonment in lieu of fines. ${ }^{22}$

\footnotetext{
${ }^{19}$ Dahlan, Op.Cit., p. 120.

${ }^{20}$ Ibid. p. 123-128.

21 Ibid. p. 288.

${ }^{22}$ Ibid. p. 289.
} 
Article 111 and Article 112 of Act No. 35 Of 2009 which use the words control, keep, and possess make it possible for every narcotics abuser to be entangled with the provisions of both articles. The unclear provisions of Article 127 of Act No. 35 of 2009 regarding in what circumstances and criteria a person can be said to be a narcotics abuser results in many irregularities in the application of Article 127 of Act No. 35 Of 2009, so that people who should be convicted as users are even subject to articles with categories possessing or controlling which results in the imposition of a sentence that is not on target, where the person should be rehabilitated to be free from dependence on narcotics, but instead is sentenced to a minimum of 4 (four) years in prison. ${ }^{23}$

In hearing a case, the judge is bound by the indictment of the public prosecutor as a guide in determining the guilt of a defendant. In the provisions of Act No. 35 Of 2009 adopting a minimum criminal system, judges are also directed to impose crimes within a certain minimum limit. In adjudicating a case, a judge not only considers legal certainty so that it is in accordance with statutory provisions but must reflect the sense of justice and benefit of all parties.

A user who is caught while in possession of narcotics will be ensnared with the provisions of Article 111 and Article 112 of Act No. 35 Of 2009, which carries a minimum penalty of 4 (four) years in prison. The application of Article 111 or Article 112 of Act No. 35 of 2009 against narcotics abusers for themselves when viewed from a legal point of view has fulfilled the provisions in accordance with the elements of the Article, but when viewed from the point of view of justice and policy, the application of the Article is the same. It is completely inappropriate because a narcotics abuser must be viewed as a victim of a narcotics crime for himself, it would be very unfair if Article 111 or Article 112 of Act No. 35 Of 2009 is applied to himself. ${ }^{24}$

In general, narcotics abusers themselves are people who are still in their productive age, who are the nation's next generation. If the narcotics abusers themselves are only jailed for years without being cured, then one can imagine the future of the convicts because in prison or correctional institutions, narcotics can be obtained. ${ }^{25}$

Sentencing themselves to prison for narcotics abusers and placing them in a correctional facility is not appropriate and wise, because narcotics abusers themselves will not recover from dependence on narcotics, and this action also causes the occupancy rate of correctional institutions. exceeding the capacity because it is true that the inmates of prisons are narcotics abusers. ${ }^{26}$

To find out when an abuser can apply the provisions of Article 127 of Act No. 35 Of 2009, it must first be known that the purpose of an abuser of buying, receiving, controlling and carrying narcotics is correct to be used for himself. Determining the purpose for which a person is in possession, possession, receiving or buying of narcotics is very important for the proper application of criminal provisions. The Supreme Court has issued Supreme Court Circular Letter Number

\footnotetext{
23 Ibid.

${ }^{24}$ Ibid. p. 289 and 291.

25 Ibid.

26 Ibid.
} 
4 of 2010 concerning the Placement of Abuse, Abuse Victims and Narcotics Addicts Into Medical Rehabilitation and Social Rehabilitation Institutions, which can be used as a reference to determine whether a person is an abuser of himself or not. ${ }^{27}$

Requirements for an addict and a victim of narcotics abuse to be rehabilitated, the judge must pay attention to the provisions of SEMA Number 4 of 2010 point 2 letter e which states that the classification of criminal acts that can be applied to punishment as referred to in Article 103 of the Narcotics Law is that the person concerned is involved in the illicit trafficking of narcotics, where one of the ways to prove this classification can be done is through an assessment by the Integrated Assessment Team. Proving that the person concerned is not involved in the illicit trafficking of narcotics is not easy because narcotics are closely related to narcotics syndicates, so that sometimes they only hide behind the guise of addicts and victims of drug abuse. ${ }^{28}$

Law enforcers ranging from investigators, the National Narcotics Agency, public prosecutors and judges must understand and be able to take the policy that narcotics abusers are victims, and sick people who need treatment so that they are not suitable for imprisonment. The imposition of imprisonment is a futile act, in which the state will also experience great losses and especially the victims will suffer more losses. ${ }^{29}$

With regard to narcotics abusers who are caught before committing narcotics abusers for themselves, probationary provisions can be applied. Furthermore, in order to have a common perception in the application of the criminal offense of narcotics abusers for himself by law enforcement officials, it is necessary to reconstruct the provisions of Article 132 paragraph (1) of Act No. 35 of 2009 into an attempted or criminal consensus to commit the crime of narcotics and narcotics precursors as intended. in Article 111, Article 112, Article 113, Article 114, Article 115, Article 116, Article 117, Article 118, Article 119, Article 120, Article 121, Article 122, Article 123, Article 124, Article 125, Article 126, 127 , and Article 129, the perpetrator will be sentenced to the same imprisonment in accordance with the provisions referred to in these Articles. ${ }^{30}$

\section{Closing}

Law enforcement in the judge's decision against the criminal act of narcotics abusers for themselves in the perspective of justice is based on the judge's consideration in determining the severity or lightness of the punishment imposed on the defendant in accordance with the principle of balance between guilt and unlawful acts. The imposition of a criminal considering the circumstances contained in the defendant, life history and social and economic conditions of the defendant can serve as a guide for a judge to pass a sentence. A narcotics abuser must be considered himself a victim of a narcotics crime, so it must be

\footnotetext{
27 Ibid.

${ }^{28}$ Ratna WP, 2017, Aspek Pidana Penyalahgunaan Narkotika, Rehabilitasi Versus Penjara (Menyoroti Pasal 127 UU No. 35 Tahun 2009), First Edition Legality, Yogyakarta, p. 38 and 39.

${ }^{29}$ Dahlan, Op.Cit., p. 292.

30 Ibid.
} 
rehabilitated. Supreme Court Circular No. 4/2010 is used as a reference for judges to determine whether a person is an abuser of himself or not.

There needs to be a common perception among law enforcers, in this case investigators, public prosecutors and judges in qualifying the same criminal sanctions against narcotics abusers for themselves. Law enforcers must see that narcotics abusers themselves are victims, so it would be fair if narcotics abusers themselves are given rehabilitation instead of imprisonment.

\section{References}

\section{Books :}

[1] Aulia Fadhli, 2018, NAPZA, Ancaman, Bahaya, Regulasi dan Solusi Penanggulangannya, First Edition Gava Media, Yogyakarta

[2] Dahlan, 2017, Problematika Keadilan Dalam Penerapan Pidana Terhadap Penyalah-guna Narkotika, First Edition Deepublish, Yogyakarta

[3] Edi Setiadi and Kristian, 2017, Sistem Peradilan Pidana Terpadu dan Sistem Pe-negakan Hukum Di Indonesia, First Edition Kencana Prenada Media, Jakarta

[4] Edi Setiadi dan Rena Yulia, 2010, Hukum Pidana Ekonomi, First Edition Edisi Pertama, Graha Ilmu, Yogyakarta

[5] Erna Dewi, Juli 2010, Peranan Hakim Dalam Penegakan Hukum Pidana Indonesia, Pranata Hukum, Vol. 5 No. 2, Faculty of Law, University of Lampung, Lampung

[6] Jawade Hafidz Arsyad dan Dian Karisma, 2018, Sentralisasi Birokrasi Pengadaan Barang \& Jasa Pemerintah, First Edition Sinar Grafika, Jakarta

[7] Jhonny Ibrahim, 2011, Teori dan Metodologi Penelitian Hukum Normatif, Bayumedia, Malang

[8] Juhaya S. Praja, 2011, Teori Hukum dan Aplikasinya, Cetakan Kesatu, Pustaka Setia, Bandung

[9] Maroni, 2016, Penegakan Hukum Pidana yang Humanistik Untuk Mewujudkan Keadilan Spiritual, dalam Sulaiman (Ed.), Pemikiran Hukum Spiritual Pluralistik, Sisi Lain Hukum yang Terlupakan, Second Edition, Thafa Media, Yogyakarta

[10] Mukti Fajar ND and Yulianto Achmad, 2010, Dualisme Penelitian Hukum Normatif dan Empiris, Pustaka Pelajar, Yogyakarta

[11] Ratna WP, 2017, Aspek Pidana Penyalahgunaan Narkotika, Rehabilitasi Versus Penjara (Menyoroti Pasal 127 UU No. 35 Tahun 2009), First Edition Legality, Yogyakarta

[12] Siti Malikhatun Badriyah, 2010, Penemuan Hukum Dalam Konteks Pencarian Keadilan, First Edition Badan Penerbit Universitas Diponegoro, Semarang

[13] Soeratno dan Lincolin Arsyad, 2003, Metodologi Penelitian Untuk Ekonomi Dan Bisnis, UPP AMP YKPN, Yogyakarta

[14] Soerjono Soekanto, 2016, Faktor-faktor yang Mempengaruhi Penegakan Hukum, First Edition, 14 Printed, Raja Grafindo Persada, Jakarta

[15] Teguh Prasetyo, 2010, Hukum Pidana, Rajawali Press, Jakarta 
[16] Theodorus Yosep Parera, 2016, Advokat dan Penegakan Hukum, First Edition Genta Press, Yogyakarta

[17] Viswandro, Maria Matilda dan Bayu Saputra, 2015, Mengenal Profesi Penegak Hukum, Buku Rujukan Berkarier Di Bidang Hukum, Hakim-Jaksa-PolisiAdvokat, First Edition Pustaka Yustisia, Yogyakarta

[18] Yasonna H. Laoly, 2019, Jerat Mematikan, Perspektif Kesejahteraan Ekonomi Dalam Penyalahgunaan Narkotika, First Edition Pustaka Alvabet, Ciputat Tangerang

\section{Journal:}

[1] Arif Hidayat dan Sri Endah Wahyuningsih, Juni 2018, Role of Prosecutor General Pro-secution of Actors in The Implementation of Abuse of Narcotics Crime (Case Study in Magelang District Attorney), Jurnal Daulat Hukum, Vol. 1 No. 2, Faculty of Law, Sultan Agung Islamic University, Semarang, p. 446. 